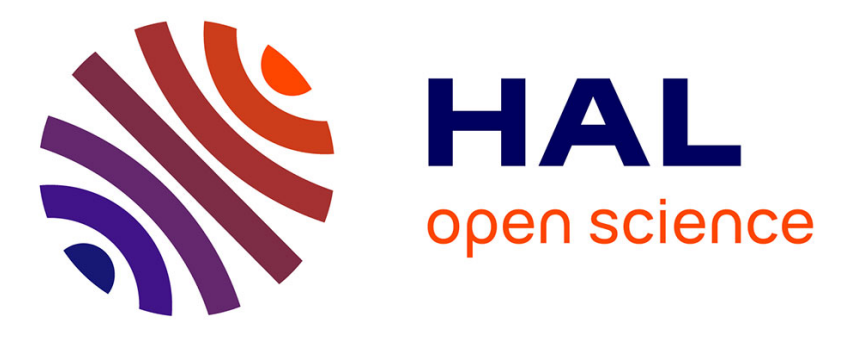

\title{
An improved night-lighting technique for the selective capture of sandgrouse and other steppe birds
}

Ana Benítez-López, François Mougeot, Carlos A. Martín, Fabián Casas, María Calero-Riestra, Jesús T. García, Javier Viñuela

\section{- To cite this version:}

Ana Benítez-López, François Mougeot, Carlos A. Martín, Fabián Casas, María Calero-Riestra, et al.. An improved night-lighting technique for the selective capture of sandgrouse and other steppe birds. European Journal of Wildlife Research, 2010, 57 (2), pp.389-393. 10.1007/s10344-010-0437-2 . hal-00626237

\section{HAL Id: hal-00626237 https://hal.science/hal-00626237}

Submitted on 24 Sep 2011

HAL is a multi-disciplinary open access archive for the deposit and dissemination of scientific research documents, whether they are published or not. The documents may come from teaching and research institutions in France or abroad, or from public or private research centers.
L'archive ouverte pluridisciplinaire HAL, est destinée au dépôt et à la diffusion de documents scientifiques de niveau recherche, publiés ou non, émanant des établissements d'enseignement et de recherche français ou étrangers, des laboratoires publics ou privés. 


\title{
An improved night-lighting technique for the selective capture of sandgrouse and other steppe birds
}

\author{
Ana Benítez-López • François Mougeot • \\ Carlos A. Martín • Fabián Casas • \\ María Calero-Riestra • Jesús T. García • Javier Viñuela
}

Received: 9 April 2010 /Revised: 8 September 2010 /Accepted: 9 September 2010 /Published online: 24 September 2010

(C) Springer-Verlag 2010

\begin{abstract}
The night-lighting technique is routinely used to catch birds. We improved this technique using a thermal infrared camera to catch steppe birds such as the sandgrouse. Target birds were located by an observer using the thermal camera, and approached and dazzled by another observer carrying a spotlight attached to a helmet and a hand-held net together with a playback noise to camouflage the footsteps of the observer. Using this improved technique, we caught on average 1.14 individuals per 3 -h capture session $(N=81)$ and a total of 92 sandgrouse in 2007-2010 (86 pin-tailed sandgrouse Pterocles alchata and six black-bellied sandgrouse Pterocles orientalis). Capture rate and success were negatively influenced by moonlight (lowest during full moon nights). Our night-lighting technique is a highly selective and harmless method to capture sandgrouse and can be used for other small/medium-sized open-land birds or mammals.
\end{abstract}

Keywords Capture - Thermal infrared camera . Night lighting $\cdot$ Sandgrouse $\cdot$ Trapping technique

A wide variety of capture methods have been used in avian field studies depending on the characteristics of the target

Communicated by C. Gortázar

A. Benítez-López $(\bowtie) \cdot$ C. A. Martín · F. Casas

M. Calero-Riestra $\cdot J$. T. García $\cdot J$. Viñuela

Instituto de Investigación en Recursos Cinegéticos,

IREC (CSIC-UCLM-JCCM),

Ronda de Toledo $\mathrm{s} / \mathrm{n}$,

13071 Ciudad Real, Spain

e-mail: Ana.Benitez@uclm.es

F. Mougeot

Estacion Experimental de Zonas Áridas (EEZA, CSIC),

Ctra. de Sacramento s/n La Cañada de San Urbano,

04120 Almería, Spain species, the capture period or the habitat (Bub 1991). The night-lighting technique consists in using a powerful light to locate (usually by light reflection from the bird's eyes) and dazzle birds at night and to approach and catch them with a hand-held net. This technique has proved highly effective for many species (e.g. red grouse, Hudson 1986; woodcocks, Duriez et al. 2005; nightjars, Forero et al. 2001), several aquatic species and owls (Hernandez et al. 2006; King et al. 1994; Labisky 1959) and is selective, allowing targeting certain species and individuals (Bub 1991; King et al. 1994; Labisky 1959). Furthermore, catching diurnal birds at night (a time of low physiological activity) might reduce the stress suffered during the capture and handling, which is especially important in the case of sensitive species (Ponjoan et al. 2008); however, this technique can be time demanding when roosts need to be located in advance or when birds are difficult to find (small size, cryptic plumage, eyes poorly reflecting the spotlight).

Here, we report on an improved night-lighting technique that allows to selectively capture pin-tailed and black-bellied sandgrouse (Pterocles alchata and Pterocles orientalis) in order to study their breeding ecology and movements (e.g. Martín et al. 2010a, b), and we also give recommendations for the optimal use of our methodology.

\section{Materials and methods}

Fieldwork was conducted in July 2007-May 2010 in different areas of Spain: Campo de Calatrava and Carrión de Calatrava in Ciudad Real province, Carrizales y Sotos de Aranjuez in Madrid province, and Bardenas Reales Natural Park in Navarra. These areas were covered by agro-steppes, natural steppes and/or ploughed fields or barren areas with low vegetation cover. Captures were performed at night 
avoiding bad weather conditions (rain, mist, strong winds) to minimise the risk of hypothermia and stress for birds. Birds were located before dusk in order to determine where they roost. Two persons were needed to guarantee both capture efficiency and bird safety during handling. One person carried a thermal infrared camera (Panatec, Madrid, Spain), the other carried the catching equipment, which consisted of (1) a hand-held net $(2.5 \times 2.5 \mathrm{~m}, 3-5 \mathrm{~cm}$ threeply netting mesh) fitted to a telescopic pole $(2.5-5 \mathrm{~m}$ length; diameter, $5 \mathrm{~cm}$ ) built in lightweight (carbon fibre) and dark-coloured (Fig. 1a, c, d) materials; (2) a plastic helmet fitted with a strong halogen spotlight $(50 \mathrm{~W})$; (3) a backpack containing the battery $(12 \mathrm{~V}-12 \mathrm{AH})$ for the spotlight; and (4) a tape player to broadcast a recording of a tractor's engine sound when approaching target birds. Captures started at least $1 \mathrm{~h}$ (winter) or $2 \mathrm{~h}$ (summer) after the sunset when the temperature dropped sufficiently to optimise the use of the thermal infrared camera and lasted until the battery of the thermal infrared camera was consumed $($ c. $3 \mathrm{~h})$. Birds were first located in darkness using the thermal infrared camera by scanning and looking for birds in the field where the roosting birds were previously located. With this camera, the shape of sandgrouse was easily recognisable from a distance of c. $100 \mathrm{~m}$
Fig. 1 a Image of a researcher carrying the large hand-held net attached to the telescopic pole and the helmet with a fitted spotlight used for trapping sandgrouse (photo taken by Faena). b Image of a researcher performing a capture attempt. c Detail of the V-shaped piece attached to the telescopic pole and $\mathbf{d}$ net assembled to the pole using the V-shaped piece

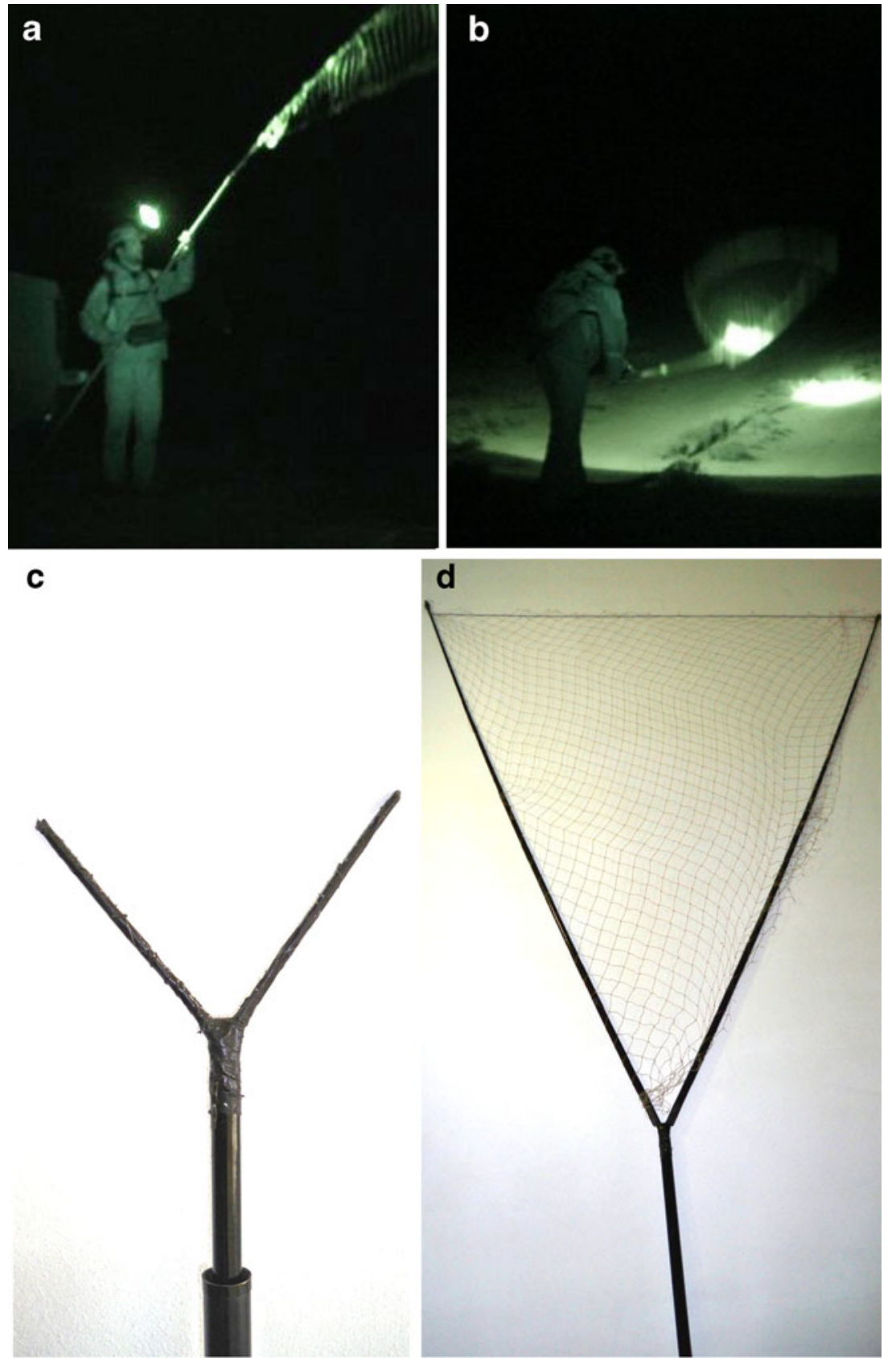


in fields with no or low vegetation (Fig. 2a, b). The camera detects the amount of infrared radiation that each object emits according to its temperature (the greater the temperature contrast between object/surroundings, the brighter the object; Fig. 2a, b, c). The system works in total darkness, but open space between the object and the camera is essential to get infrared radiation. Thus, bird detection is possible in open areas with no or short vegetation (for sandgrouse, on bare grounds, ploughs or 1-year fallows). Once a target individual was located with the camera, the
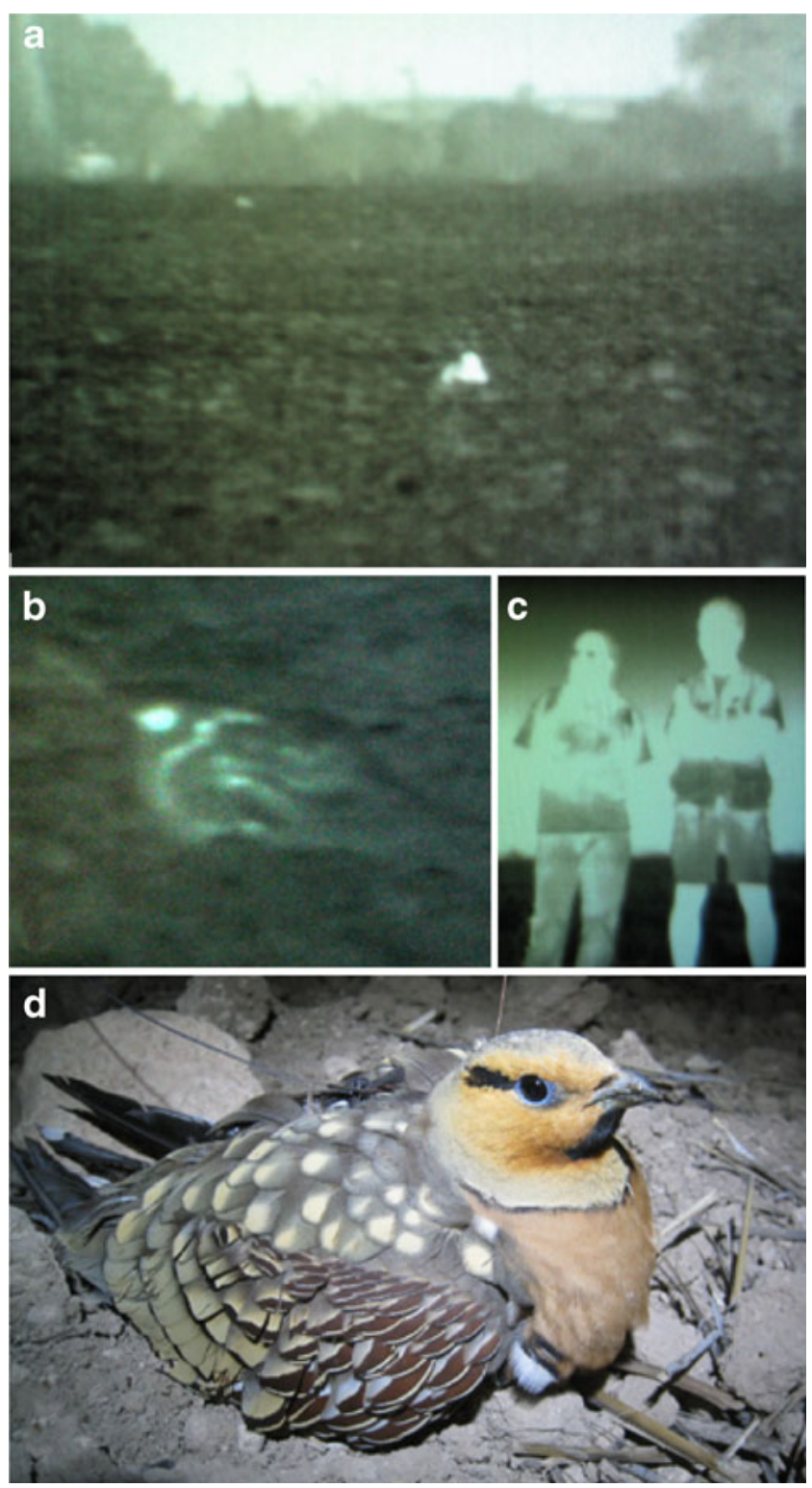

Fig. 2 a Image of sandgrouse in a ploughed field viewed through the thermal infrared camera (distance of c. $100 \mathrm{~m}$ ). b Close-up view of a pin-tailed sandgrouse through the thermal infrared camera (distance $\mathrm{c}$. $10 \mathrm{~m}$ ). c A pair of researchers as viewed through the thermal infrared camera. d Male pin-tailed sandgrouse prior to release (photos taken by F. Mougeot) bird was pinpointed to the second observer who approached and dazzled it with the spotlight while playing the taperecorded noise to camouflage footstep noise. When the individual was close enough (c. 3-4 m), the net was rapidly swung downward over the bird to capture it (Figs. 1b, 2d).

To assess the efficiency of our method, we recorded capture success $(1=$ one or more birds captured/session, $0=$ unsuccessful session) and capture rate (number of birds captured/session, each session lasting c. $3 \mathrm{~h} ; N=81$ sessions). We also recorded the number of attempts/session and the number of birds captured/attempt for 26 out of the 81 sessions (an attempt was performed when an observer managed to approach an individual and swing the net over). We recorded several variables (season, moon phase and wind speed) that could affect capture success and capture rate (moonlight might influence awareness and intruder's detection; wind might reduce the noise of an approaching intruder). Moonlight was coded as 0 (new moon \pm 3 days or moon absent or hidden by clouds), 1 (increasing or decreasing half moon phase \pm 3 days, moon present and not obscured by clouds) or 2 (full moon phase \pm 3 days, moon present and not obscured). Average wind speed was recorded as a continuous variable (in kilometres per hour, MARM 2010) and season as categorical variable: prebreeding (March/May), breeding (June/mid-August), postbreeding (mid-August/September) and winter (October/ February). We tested the effect of these variables on the capture success (binomial distribution) and the capture rate (Poisson distribution) using GLMs and the function "step"/ backward direction in R 2.10 (R Development Core Team 2009) to select the best model out of our candidate models [the model with the lowest second-order Akaike Information Criterion]. Akaike weights were calculated to determine the probability that each model in the candidate set is the best model as an inference (Burnham and Anderson 2002). We calculated the importance weight for each variable included in our candidate models to determine their relative importance in predicting capture success or rate (Burnham and Anderson 2002).

\section{Results}

We captured 92 sandgrouse (86 pin-tailed sandgrouse, 50 males, 33 females and three juveniles; and six black-bellied sandgrouse, four males and two juveniles). Most captures were performed during winter $(N=34)$ and pre-breeding $(N=34)$ periods followed by post-breeding $(N=17)$ and breeding $(N=7)$ periods. Birds were always apparently calm when captured and flew upon release. No individual died when captured or handled. On average, 1.14 individuals (range, $0-4)$ were captured per session $(N=81)$ out of 2.08 attempts per session (range, $1-4 ; N=26$ ). 
Table 1 Results of generalised linear models testing for the effects of moonlight (moon), wind speed (wind) and season on capture success and capture rate. The best models appear in bold.

\begin{tabular}{|c|c|c|c|c|c|c|}
\hline Variable & Model & AICc & $K$ & $\Delta_{i} \mathrm{AICc}$ & $w_{\mathrm{i}}$ & \% Dev. \\
\hline \multirow[t]{4}{*}{ Capture success } & Moon & 110.85 & 3 & $\mathbf{0 . 0 0}$ & 0.69 & 2.73 \\
\hline & Moon+wind & 112.66 & 4 & 0.38 & 0.25 & 2.90 \\
\hline & Moon + wind + season & 115.53 & 5 & 1.11 & 0.05 & 5.81 \\
\hline & Moon + wind + season + moon $\times$ wind & 118.51 & 6 & 3.12 & 0.01 & 6.75 \\
\hline \multirow[t]{4}{*}{ Capture rate } & Moon & 226.31 & 3 & $\mathbf{0 . 0 0}$ & 0.72 & 7.94 \\
\hline & Moon+wind & 228.30 & 4 & 1.88 & 0.24 & 7.94 \\
\hline & Moon + wind + moon $\times$ wind & 231.77 & 5 & 4.23 & 0.04 & 8.46 \\
\hline & Moon + wind + season + moon $\times$ wind & 235.85 & 6 & 8.32 & 0.00 & 10.31 \\
\hline
\end{tabular}

Capture success and capture rate were fitted to models using binomial and Poisson error distributions, respectively

AIC : second-order Akaike Information Criterion, $K$ : no of estimated parameters, $\Delta_{i} A I C c$ : difference between the model AICc and the lowest AICc for the model set, $w_{\mathrm{i}}$ : Akaike weight (relative likelihood of each model: the smaller the weight the less plausible the model), \% Dev: percentage of deviance explained by the model [(null deviance-residual deviance)/null deviance $\times 100$ ]

The models containing moonlight or moonlight+wind best explained capture success (Table 1), the former being 2.76 times more likely to be the best explanation for capture success than the latter. The same held for capture rate (Table 1) with the moonlight model being three times more likely to explain capture success than the moonlight + wind model. The variable moonlight turned out to be $3.23^{1}$ and $3.57^{2}$ times more plausible than wind speed for explaining capture success and capture rate, respectively. Both capture success (mean $\pm \mathrm{SE}, 0.70 \pm 0.09)$ and capture rate $(1.50 \pm$ $0.21, N=30$ ) were greater in dark overcast nights and in half moon nights (success, $0.62 \pm 0.08$; rate, $1.05 \pm 0.18, N=37$ ) than in clear moonlit nights (success, $0.43 \pm 0.14$; rate, $0.57 \pm$ $0.23, N=14$ ). Wind speed had a slight, negligible negative effect on capture success (effect size $\pm \mathrm{SE}=-0.014 \pm$ $0.031)$ and rate $(-0.001 \pm 0.014)$.

\section{Discussion}

The improved night-lighting technique presented here was highly successful for capturing sandgrouse. Greater effectiveness was achieved in "dark", overcast nights with no or little moonlight (i.e. new moon or cloudy increasing/ decreasing moon phase) and in light wind conditions; however, our models explained little of the variation in capture rate or success (see deviances in Table 1), so other factors not considered here such as habitat type, equipment (length of the pole, size of the net, intensity of spotlight), observer's experience or simply chance, are likely to also

\footnotetext{
${ }^{1}$ Model for capture success: importance weight for moonlight $=1$, importance weight for wind speed $=0.31$

${ }^{2}$ Model for capture rate: importance weight for moonlight $=1$, importance weight for wind speed $=0.28$
}

explain success. We did not record habitats where capture attempts were successful or not, but our experience suggest that attempts on ploughs might be more successful because we are better able to detect birds with the thermal camera without vegetation and because walking on substrates with dry vegetation generates more noise. We also noticed that using a longer pole, a larger net and more powerful spotlight may enhance success.

Other causes of failure that are easy to avoid through practice and experience are (1) failing to properly dazzle the target individual (spotlight not always aimed at the bird when approaching); (2) failing to detect a bird closer than the target individual, which flushes before the target bird, causing other birds to flush; (3) lighting the net when swung downwards, allowing the target bird to see it before capture and (4) dropping the net too far/close from the bird or failing to locate the bird with the spotlight from a very close distance.

The primary advantages of this improved trapping technique are that it allows the selective capture of individuals of diurnal species with low injury rate and reduced capture stress. This technique also allowed us to catch other birds such as red-legged partridges Alectoris rufa (Casas et al. 2009), stone curlews Burhinus oedicnemus or passerines (larks) and even mammals (juvenile Iberian hares Lepus granatensis). Thus, its applicability goes beyond capturing sandgrouse and it can be easily adapted for capturing other open-land birds and mammals.

Acknowledgements We thank A. Urmeneta, S. González, Faena, C. Ponce, C. Bravo, F. Alda, S. Luna and A. Mateo for their help during fieldwork; the owners for allowing us to work in their properties and the Regional governments for capture permits. Funding came from the Dirección General de Investigación (projects CGL2007-66322/BOS and CGL2008-04282/BOS), Consejería de Educación y Ciencia de Castilla-La Mancha (projects PAI08-0171-9582 and PAC06-137) and Bardenas Reales Natural Park (project CTR09-0268). 


\section{References}

Bub H (1991) Bird trapping and bird banding: a handbook for trapping methods all over the world. Cornell University Press, Ithaca

Burnham K, Anderson D (2002) Model selection and multimodel inference: a practical information-theoretic approach. Springer, New York

Casas F, Mougeot F, Viñuela J (2009) Double-nesting behaviour and sexual differences in breeding success in wild red-legged partridges Alectoris rufa. Ibis 151:743-751

Duriez O, Eraud C, Barbraud C, Ferrand Y (2005) Factors affecting population dynamics of Eurasian woodcocks wintering in France: assessing the efficiency of a hunting-free reserve. Biol Cons 122:89-97

Forero M, Tella J, Oro D (2001) Annual survival rates of adult rednecked nightjars Caprimulgus ruficollis. Ibis 143:273-277

Hernandez F, Harveson L, Brewer C (2006) A comparison of trapping techniques for Montezuma Quail. Wildl Soc Bull 34:1212-1215

Hudson PJ (1986) The red grouse: the biology and management of a wild gamebird. The Game Conservancy Trust, Fordingbridge
King D, Andrews K, King J, Flynt R, Glahn J, Cummings J (1994) A night-lighting technique for capturing cormorants. J Field Ornithol 65:254-257

Labisky RF (1959) Night-lighting: a technique for capturing birds and mammals. Ill Nat Hist Surv Biol Notes 40:1-11

MARM (2010) SIAR: Sistema de Información Agroclimática para el Regadío. Available at www.mapa.es/siar/. Accessed on March 5, 2010

Martín CA, Casas F, Mougeot F, García JT, Viñuela J (2010a) Positive interactions between vulnerable species in agrarian pseudosteppes: habitat use by pin-tailed sandgrouse depends on its association with the little bustard. Anim Conserv 13:383-389

Martín CA, Casas F, Mougeot F, García JT, Viñuela J (2010b) Seasonal variations in habitat preferences of the pin-tailed sandgrouse in agrarian pseudo-steppes. Ardeola 57:191-198

Ponjoan A, Bota G, De La Morena E, Morales M, Wolff A, Marco I, Mañosa S (2008) Adverse effects of capture and handling little bustard. J Wildl Manage 72:315-319

R Development Core Team (2009) R: a language and environment for statistical computing. R Foundation for Statistical Computing, Vienna. Available at http://www.R-project.org. Accessed on July 3, 2010 